Doi: HTTPS://DOI.ORG/10.23910/IJBSM/2017.8.3.1722

\title{
Economics of Maize (Zea mays L.) and Soybean (Glycine max (L.) Merrill) Intercropping
}

\author{
Lowrence Kithan* and L. Tongpang Longkumer
}

Dept. of Agronomy, School of Agricultural Sciences and Rural Development, Nagaland University, Medziphema Campus, Nagaland (797 106), India

Corresponding Author

Lowrence Kithan

e-mail: lowrencekithan@gmail.com
Article History

Manuscript No. AR1722

Received in $27^{\text {th }}$ October, 2016

Received in revised form $11^{\text {th }}$ April, 2017

Accepted in final form $6^{\text {th }}$ June, 2017

\begin{abstract}
A study was conducted during kharif, 2015 at the experimental farm of School of Agricultural Sciences and Rural Development (SASRD) Nagaland University, Medziphema Campus, Nagaland under rainfed condition. The treatments comprised of different row ratios i.e. (1:1), (1:2), (2:1), (2:2) and (2:3) respectively of maize (Var. Dekalb All-Rounder) intercropped with soybean (Var. JSS-335) along with sole crops of maize and soybean. The experiment was laid in RBD with 4 replications and 7 treatments. Both maize and soybean as sole crops performed better in respect of growth characters such as plant height $(\mathrm{cm})$, number of leaves plant ${ }^{-1}$, number of root nodules plant ${ }^{-1}$, root length $\left(\mathrm{cm}^{2}\right)$, and yield attributing characters viz.,cob weight $(\mathrm{g})$, cob length $(\mathrm{cm})$, number of pods plant ${ }^{-1}$, grain yield $\left(26.99 \mathrm{q} \mathrm{ha}{ }^{-1}\right)$, seed yield $(21.75 \mathrm{q}$ $\left.\mathrm{ha}^{-1}\right)$ and B: $\mathrm{C}(0.85,1.63)$ than in intercropping systems. Among the intercropping systems, paired rows $(2: 2)$ ratio of maize and soybean proved superior to all other treatments in respect of growth and yield attributing characters, grain yield of maize $\left(23.08 \mathrm{q}\right.$ ha $\left.{ }^{-1}\right)$, seed yield of soybean (20.34 q ha-1), Gross return ( $₹$ 100256), Net return ( $₹ 75472$ ), LER (1.80) and B:C ratio (3.04). In a nutshell, based on the value of growth functions and yield attributing characters, paired (2:2) rows of maize and soybean was found to be biologically efficient system. As on economic indices of land equivalent ratio the system paired rows (2:2) was found to be economically profitable system for kharif seasons under rainfed season in Nagaland.
\end{abstract}

Keywords: Sole crops, intercropping, growth, yield, economics, LER

\section{Introduction}

Maize (Zea mays L.) ranks second to wheat in world cereal production and it is the most widely grown among the major crop species, with more than 70 countries planting maize on at least 100,000 ha, including 53 developing countries. On a global basis, two-thirds of all maize is used as animal feed, although it also constitutes a staple food for the populace of several countries in Latin America, Africa and Asia. With a rise in standard of living and to fetch higher prices from maize cultivation, an increase in maize area for its diversified use like pop corn, sweet corn, baby corn, quality protein maize etc is being noticed particularly in peri-urban agriculture. maize or corn is the third most important crop in India after rice and wheat grown over 8.67 mha with $22.26 \mathrm{mt}$ production having an average productivity of $2566 \mathrm{~kg} \mathrm{ha}^{-1}$, contributing $8 \%$ in national food basket (DACNET, 2014). In India, maize is cultivated in 8.6 mha with a production of 20.5 metric $t$ and the average yield is $2.4 \mathrm{t} \mathrm{ha}^{-1}$ (Anonymous, 2011). The area, production and productivity of maize for the year 2012-2013 under Nagaland was $63530 \mathrm{ha}, 124580 \mathrm{mt}$ and $1960 \mathrm{~kg} \mathrm{ha}^{-1}$ (kharif) and 5140 ha, 10070 metric t and $1960 \mathrm{~kg} \mathrm{ha}^{-1}$ (rabi) (Anonymous, 2014).
Soybean (Glycine max (L.) Merrill) is an important and a major oilseed crop of the world. According to FAO estimates, over $160 \mathrm{mt}$ of soybean was produced worldwide in 2000. Being a leguminous crop, it restores the fertility of the soil by fixing large amount of atmospheric nitrogen i.e. $125-150 \mathrm{~kg} \mathrm{~N} \mathrm{ha}^{-1}$ through nodules (Chandel et al., 1989) and by leaves about 30-40 kg N ha-1 for succeeding crops (Saxena and Chandel, 1992).

In Nagaland, The area, production and productivity of soybean for the year 2012-2013 under Nagaland was 24.67 thousand ha, $30880 \mathrm{mt}^{2}$ and $1251 \mathrm{~kg} \mathrm{ha}^{-1}$ (kharif) (Anonymous, 2014). It is one of the most popular food items of majority of the people of Nagaland and is utilized as a pulse crop and as fermented products locally called as 'Akhuni'.

Intercropping of legumes with cereals like maize (Zea mays L.) economizes the use of nitrogen fertilizer and increases the production unit ${ }^{-1}$ area (Singh et al., 1986). For successful and profitable intercropping system, there must be proper row ratio of component crop in order to avoid limitation of reduced plant population of base crop under traditional inter-cropping system (Pandey et al., 1999). 


\section{Materials and Methods}

An experiment was conducted at the experimental farm of School of Agricultural Sciences and Rural Development Medziphema, Nagaland, under rainfed condition during the Kharif of 2011 to study the performance of maize+soybean intercropping over sole crops of maize and soybean. The experimental site is located at $25^{\circ} 45^{\prime} 43^{\prime \prime}$ North latitude and $93^{\circ} 53^{\prime} 04^{\prime \prime}$ East longitude at an altitude of $310 \mathrm{~m} \mathrm{MSL}$. The prevailing climate represents sub-humid tropical climatic zone with high relative humidity, moderate temperature and medium to high rainfall. The mean temperature ranges from 21 ${ }^{\circ} \mathrm{C}$ to $30^{\circ} \mathrm{C}$ during summer and rarely goes below $8^{\circ} \mathrm{C}$ in winter due to high atmospheric humidity. The average rainfall varies between 2,000 and 2,500 mm starting from April and ends with the month of September while the period from October to March remains completely dry. The soil of the experiment plot was categorized as sandy loam and well drained. The experiment was conducted in randomized block design with 4 replications. The seven treatments in the experiment were comprised of sole maize, sole soybean, and maize+soybean in the row ratios of $1: 1,1: 2,2: 1,2: 2$ and $2: 3$, respectively. The varieties used for maize and soybean were Dekalb All Rounder and JS-335 respectively. Fertilizer application @ 100:80:60 kg N:P $\mathrm{O}_{5}: \mathrm{K}_{2} \mathrm{O}$ was made as recommendation ${ }^{-1}$. Plant protection measures such as Malathion dust @ 25 kg ha $^{-1}$ and Chlorpyriphos 20\% EC were applied.

\section{Results and Discussion}

\subsection{Growth parameters}

Significantly taller plants of maize was observed in sole maize than the intercropping treatments at 25 DAS, 50 DAS and 75 DAS. At harvest also, maize plants were taller in sole maize than the intercropping treatments though those were statistically similar (Table 1 and 2). This might

Table 1: Effects of maize (Zea mays L.) and soybean (Glycine max (L.) Merrill) intercropping on growth and yield parameters of maize

\begin{tabular}{|c|c|c|c|c|c|c|c|c|}
\hline Treatments & $\begin{array}{c}\text { Plant } \\
\text { height }(\mathrm{cm})\end{array}$ & $\begin{array}{l}\text { No. of } \\
\text { leaves }\end{array}$ & $\begin{array}{c}\text { No. of cobs } \\
\text { plant }^{-1}\end{array}$ & $\begin{array}{c}\text { Cob weight } \\
\text { (g) }\end{array}$ & Grains cob-1 & $\begin{array}{l}\text { Cob length } \\
(\mathrm{cm})\end{array}$ & $\begin{array}{c}\text { Test weight } \\
\text { (g) }\end{array}$ & $\begin{array}{c}\text { Grain yield } \\
(\mathrm{q} \mathrm{ha-1})\end{array}$ \\
\hline $\mathrm{T}_{1}$ & 236 & 8.53 & 1.9 & 213.4 & 440.93 & 17.6 & 282.5 & 26.99 \\
\hline $\mathrm{T}_{2}$ & - & - & - & - & - & - & - & - \\
\hline $\mathrm{T}_{3}$ & 230.33 & 6.66 & 1.6 & 107 & 321.4 & 15.6 & 244.16 & 21.52 \\
\hline $\mathrm{T}_{4}$ & 219.86 & 8.26 & 1.65 & 95.53 & 306.73 & 14.53 & 256.66 & 21.91 \\
\hline $\mathrm{T}_{5}$ & 231.26 & 8.06 & 1.7 & 115.8 & 349.46 & 15.86 & 265.83 & 22.3 \\
\hline $\mathrm{T}_{6}$ & 234.66 & 6.73 & 1.8 & 121.4 & 387.33 & 16.66 & 277.5 & 23.08 \\
\hline $\mathrm{T}_{7}$ & 229 & 8.46 & 1.5 & 119.93 & 304 & 16.4 & 257.5 & 19.17 \\
\hline SEm \pm & 2.96 & 0.12 & 0.10 & 7.14 & 27.23 & 0.41 & 9.24 & 1.12 \\
\hline $\operatorname{CD}(p=0.05)$ & 8.91 & 0.36 & NS & 21.53 & 82.05 & 1.25 & NS & 3.38 \\
\hline
\end{tabular}

$\mathrm{T}_{1}$ : Sole maize; $\mathrm{T}_{2}$ : Sole soybean; $\mathrm{T}_{3}$ : Maize+soybean (1:1); $\mathrm{T}_{4}$ : Maize+soybean (1:2); $\mathrm{T}_{5}$ : Maize+soybean (2:1); $\mathrm{T}_{6}$ : Maize+soybean $(2: 2) ; T_{7}:$ Maize+soybean $(2: 3)$

Table 2: Effect of maize (Zea mays L.) and soybean (Glycine max (L.) Merrill) intercropping on growth parameters of soybean

\begin{tabular}{lccccc}
\hline Treatments & PH & NNP & NBP & RL & NPP \\
\hline $\mathrm{T}_{1}$ & - & - & - & - & - \\
$\mathrm{T}_{2}$ & 94.06 & 6.66 & 10.53 & 29.46 & 50.20 \\
$\mathrm{~T}_{3}$ & 83.66 & 6.26 & 10.20 & 28.26 & 34.86 \\
$\mathrm{~T}_{4}$ & 85 & 6.40 & 10.26 & 27.33 & 34.53 \\
$\mathrm{~T}_{5}$ & 88.8 & 6.40 & 10.26 & 27.60 & 49.53 \\
$\mathrm{~T}_{6}$ & 92.46 & 6.53 & 10.40 & 28.80 & 49.60 \\
$\mathrm{~T}_{7}$ & 73.86 & 6.40 & 10.13 & 28.53 & 38.20 \\
$\mathrm{SEm} \pm$ & 2.45 & 0.16 & 0.28 & 0.43 & 2.99 \\
$\mathrm{CD}(p=0.05)$ & 7.39 & NS & NS & 1.30 & 9.04 \\
\hline
\end{tabular}

PH: Plant height (cm); NNP: No. of nodules Plant ${ }^{-1}$ at 50 DAS; NBP: No. of branches Plant ${ }^{-1}$ at 50 DAS; RL: Root length $(\mathrm{cm})$; NPP: No. of pods plant ${ }^{-1}$ be due to the absence of intercrop competition in sole maize. Among the intercropping treatments paired rows of maize+soybean recorded the tallest plant height. This might be due to better spatial complementarily of the component crops that led to better utilization of growth resources. Rathore (1980) also found taller plants in paired rows than alternate rows in intercropping of maize with soybean, Aye (2013) on sunflower and soybean and Yhokha (2015) on soybean based intercropping on weed dynamics. But intercropping treatments showed less plant height which was in conformity with Thattil and Costawa (1991) who did an experiment on maize and mungbean. Maximum number of leaves was recorded in sole maize and among the intercropping maximum number of leaves was recorded in 2:2 ratios of maize and soybean. This might be due to poor utilization of growth resources in 2:2 ratios of maize and soybean. Sole crop performed better than intercrops. While among the intercropping 2:2 row ratio performed better 
than all the other intercrop treatments. Maximum number of nodules plant ${ }^{-1}$ was recorded in sole soybean and among the intercropping maximum number of nodules plant ${ }^{-1}$ was recorded in 2:2 ratios of maize and soybean. This might be due to poor utilization of growth resources in 2:2 ratios of maize and soybean. Maximum number of branches plant ${ }^{-1}$ was recorded in sole soybean and among the intercropping highest number of branches plant ${ }^{-1}$ was recorded in 2:2 ratios of maize and soybean. This might be due to poor utilization of growth resources in 2:2 ratios of maize and soybean. The maximum grain yield was recorded in sole crop as there was no competition for space, moisture, nutrients etc. as compared to intercropping treatments.

\subsection{Yield parameters}

Maximum number of cobs plant ${ }^{-1}$, number of seeds cob $^{-1}$ and length of cobs was recorded in sole maize. This is in conformity with Mahapatra and Pradhan (1992) who also reported reduction in cob yield in intercropped treatments in an intercropping experiment involving maize and Rice Bean. Among the intercropping treatments paired rows of maize and soybean performed better with regard to number of cobs plant ${ }^{-1}$, number of seeds cobs $^{-1}$ and length of cobs which might be due to efficient utilization of solar radiation and appropriate utilization of $\mathrm{N}_{2}$ due to mutual co-operation between the two crops. Among the intercropping treatments, $2: 2$ rows of maize+soybean were found to be superior in respect of maize and soybean yield (Table 3 ). This might be due to appropriate mutual co-operation for atmospheric nitrogen by leguminous plant in 2:2 rows. This is supported by Buiro et al. (1991) who did intercropping of maize and mung bean. This was also confirmed by the findings of Mahapatra and Pradhan (1992) whose intercropping was on maize and Cowpea. The maximum straw yield for both maize and Soybean was recorded in sole cropping due to various yield attributing characters like maximum plant height, higher

Table 3: Effect of maize (Zea mays L.) and soybean (Glycine $\max (\mathrm{L}$.$) Merrill) intercropping on yield parameters of$ soybean

\begin{tabular}{lccccc}
\hline Treatments & PW & NSP & TW & SY & SY $^{*}$ \\
\hline $\mathrm{T}_{1}$ & - & - & - & - & - \\
$\mathrm{T}_{2}$ & 21.25 & 3.26 & 36.35 & 21.75 & 32 \\
$\mathrm{~T}_{3}$ & 18.25 & 3.13 & 32.82 & 18.54 & 24.1 \\
$\mathrm{~T}_{4}$ & 19 & 3.2 & 33.33 & 18.39 & 24.02 \\
$\mathrm{~T}_{5}$ & 18.5 & 3.2 & 32.80 & 16.82 & 19.56 \\
$\mathrm{~T}_{6}$ & 20.75 & 3.2 & 33.90 & 20.34 & 25.43 \\
$\mathrm{~T}_{7}$ & 20 & 3.06 & 32.13 & 19.17 & 24.09 \\
$\mathrm{SEm} \pm$ & 0.63 & 0.10 & 0.88 & 0.59 & 0.95 \\
$\mathrm{CD}(p=0.05)$ & 1.91 & $\mathrm{NS}$ & $\mathrm{NS}$ & 1.78 & 2.87 \\
\hline $\mathrm{PW}: \mathrm{POdW}$
\end{tabular}

PW: Pod weight (g); NSP: No. of seed Pod ${ }^{-1}$; TW: Test weight (g); SY: Seed yield (q ha-1); SY*: Stover yield (q ha-1) number of leaves leading to higher straw yield of maize and soybean. But among the intercropping treatments 2:2 row ratio performed reasonably better than others, which might be due to efficient utilization of solar radiation in 2:2 row arrangement.

\subsection{Economics}

Land Equivalent Ratio (LER) gives the accurate assessment of biological efficiency of intercropping over pure cropping. LER for all the treatments were calculated in all the intercropping treatments and it was found to be greater than 1. Similar findings were reported by Buragohain and Buruah (1992 in maize and cowpea, and maize and mung bean respectively. The highest LER value was obtained from $2: 2$ ratios and it was $1.80 \%$ which indicates percent yield advantage over sole crops and it was statistically significant. This was in conformity with the findings of Mahapatra and Pradhan (1992) who observed in intercropping on maize and soybean and Fuente et al. (2014) in sunflower and soybean intercropping. Among the intercropping treatments, maize+soybean in paired ratios recorded higher gross return which attributed to the fact that price of Soybean is higher than other pulses. A higher gross return in sole maize and sole soybean crop was due to the higher grain yield of both the crops. The highest net return was recorded in paired rows of maize+soybean. Higher yields of both the component crops without incurring any extra cost of cultivation resulted in higher net return in this treatment. This was also in conformity with the findings of Mahapatra and Pradhan (1992) that did an intercropping with maize and rice bean and Uddin et al. (2014) who did an intercropping on blackgram and rice. Benefit:cost ratio was maximum in 2:2 ratios of maize+soybean which might be due to highest net return, though cost of cultivation was almost same as other intercropping treatments. This was in conformity with Mahapatra and Pradhan (1992) findings on maize and cow pea intercropping (Table 4).

Table 4: Economics of maize (Zea mays L.) and soybean (Glycine max (L.) Merrill) intercropping

\begin{tabular}{lcccc}
\hline Treatments & $\begin{array}{c}\text { Gross } \\
\text { return } \\
(₹)\end{array}$ & $\begin{array}{c}\text { Net } \\
\text { return } \\
(₹)\end{array}$ & $\begin{array}{c}\text { Benefit } \\
\text { cost ratio }\end{array}$ & $\begin{array}{c}\text { Land equiva- } \\
\text { lent ratio } \\
(\text { LER })\end{array}$ \\
\hline $\mathrm{T}_{1}$ & 45900 & 21116 & 0.85 & 1.0 \\
$\mathrm{~T}_{2}$ & 65250 & 40466 & 1.63 & 1.0 \\
$\mathrm{~T}_{3}$ & 92234 & 67450 & 2.72 & 1.65 \\
$\mathrm{~T}_{4}$ & 92417 & 67633 & 2.73 & 1.67 \\
$\mathrm{~T}_{5}$ & 88370 & 63586 & 2.56 & 1.60 \\
$\mathrm{~T}_{6}$ & 100256 & 75472 & 3.04 & 1.80 \\
$\mathrm{~T}_{7}$ & 90099 & 65315 & 2.63 & 1.60 \\
$\mathrm{SEm} \pm$ & & & & 0.04 \\
$\mathrm{CD}(p=0.05)$ & & & & 0.11 \\
\hline
\end{tabular}




\section{Conclusion}

Both sole crop performed better and among the different intercropping systems paired row (2:2) ratios of maize+soybean is the best combination for getting advantages in intercropping when compared with other row arrangements such as (1:1), $(1: 2),(2: 1)$ and $(2: 3)$ as judged by the favourable economic indices like net return, gross return, B:C ratio and Land Equivalent Ratio (LER).

\section{References}

Anonymous., 2011. Salient Achievements of AICRP maize. Directorate of Maize Research, New Delhi, India.

Anonymous., 2014. District wise Achievement of Area, Production and Yield for the year 2012-2013 in respect of Nagaland State. Directorate of Agriculture, Nagaland, Kohima, 1-7.

Aye N., 2013. Study of sunflower and soybean intercropping and their effect on weed parameters. M.Sc. (Ag) Thesis, Nagaland University, Medziphema.

Buragohain, S.K., Baruah, A.R., 1992. Performance of maize and sorghum fodder in monoculture and in association with annual legume under rainfed condition. Range Management and Agro Forestry 13(2), 171-174.

Buiro, U.A., Ahmed, K., Kumbar, A.K., Jamro, G.H., Sethar, M.A., 1991. Effect of intercropping on growth, yield and components of maize. Field Crops Abstract 44(8), 325-327.

Chandel, A.S., Pandey, K.N., Saxena, S.C., 1989. Symbiotic nitrogen benefits by modulated soybean to inter-planted crops in northern India. Tropical Agriculture 66(10), 73-77.

DACNET., 2014. Directorate of Economics and Statistics, DAC, Ministry of Agriculture, Government of India, New Delhi.
http://eands.dacnet.nic.in/StateData_12-13Year.htm.

Fuente, E.B., de la suarez, S.A., Lenardis, A.E., Poggio, S.L., 2014. Intercropping sunflower and soybean in intensive farming systems: evaluating yield advantage and effect on weed and insect assemblages. Wageningen Journal of Life Sciences 70/71, 47-52.

Mahapatra, B.K, Pradhan, L., 1992. Intercropping fodder legumes with maize in different planting patterns. Annals of Agricultural Research 13(4), 366-371.

Pandey, A.K., Prakash, V., Singh, R.D., Mani, V.P., 1999. Effect of intercropping pattern of maize and soybean on yield and economic under mid hills of N-W Himalayas. Annals of Agricultural Research 20(3), 354-359.

Rathore, S.S., Chauhan, G.S., Singh, H.G., 1980. Stand geometry of maize and its intercropping with pulses under dryland agriculture. Indian Journal of Agronomy 25(3), 319-322.

Saxena, S.C., Chandel, A.S., 1992. Effect of nitrogen fertilization on different varieties of soybean. Indian Journal of Agricultural Sciences 62(10), 695-697.

Singh, P., Agnihotri, R.C., Mittal, S.P., Agnihotri, Y., 1986. Studies on intercropping of legumes with maize in Shiwalik foot hill region. Indian Journal of Soil Conservation 14(1), 251-154.

Thattil, R.D., Costawa, J.M.D.E., 1991. Spacing experiment on maize and mungbean intercropping system design. Tropical Agriculturist 144, 109-122.

Uddin, M.S., Sarkar, M.A.R., Miah, M.A.M., 2014. Intercropping AUS rice with different seed rates of blackgram as fodder. SAARS Journal of Agriculture 12(1), 9-19.

Yhokha, K., 2015. Study of soybean based intercropping on weed dynamics. M.Sc.(Ag) Thesis, Nagaland University, Medziphema. 